\title{
Armut işletmelerinin teknik özellikleri: Antalya ili Korkuteli ilçesi örneği
}

\author{
Technical characteristics of pear-growing farms: A case of Korkuteli district of Antalya province \\ Fidan Merve KART ${ }^{1 / \mathscr{O}}$, Mevlüt GÜL ${ }^{1}$ (D) \\ ${ }^{1}$ Isparta University of Applied Sciences, Faculty of Agriculture, Department of Agriculture Economics, Isparta,Turkey.
}

MAKALE BILGISI / ARTICLE INFO

Makale tarihçesi / Article history:

DOI: $10.37908 /$ mkutbd. 787660

Geliş tarihi /Received:28.08.2020

Kabul tarihi/Accepted:28.09.2020

\section{Keywords:}

Antalya, Korkuteli, pear, technical characteristics, cultivation.

\footnotetext{
Corresponding author: F. Merve KART

$\bowtie$ : fmervekart@gmail.com
}

\section{ÖZET / A B STR A C T}

Atıf / Citation: Kart FM, Gül M (2021) Technical characteristics of pear-growing farms: A case of Korkuteli district of Antalya province. MKU. Tar. Bil. Derg. 26(1) : 63-74. DOI: 10.37908/mkutbd.787660

\begin{abstract}
Aims: In this study, it was aimed to determine the input and cultural processes used by agricultural enterprises engaged in pear production in Antalya province Korkuteli district.

Methods and Results: Within the scope of the research, primary data were obtained from 96 pear farms by face to face questionnaire method. The research data belonged to the 2018 production period. In the study, the knowledge of the producers on pear production, the varieties they grow, the number of trees, the cultural processes they applied, the use of inputs and the diseases and pests that were most affected were determined. The farms were grouped by pear area. The obtained findings were given in cross tables. The interviewed producers had 27.75 years of experience in agriculture and 22.93 years of experience in pear production. More than half of the producers (52.21\%) reported a high level of knowledge on pear cultivation. A significant portion of the farmers (74.04\%) stated that they are not satisfied with pear cultivation. In the region where the study was conducted, almost all of the producers (93.75\%) were applying the classical breeding system. It was determined that $48.56 \%$ of the pear area of the farmers interviewed in the research area was Korkuteli Karyağdı variety and $28.13 \%$ Margarite variety. It was determined that the most important disease was fire blight, and the most important pest was pear psyllid. It was calculated that the interviewed enterprises used $45.71 \mathrm{~kg}$ of nitrogen, $35.46 \mathrm{~kg}$ of phosphorus and $10.04 \mathrm{~kg}$ of potassium per decare in pear production. In addition, the average amount of fungicide per decare used in pear production was $1182.26 \mathrm{~g}$, insecticide amount $403.90 \mathrm{~g}$ and herbicide amount was calculated as $166.73 \mathrm{~g}$.

Conclusions: It was determined that the producers in the region have a high level of experience and knowledge in pear production. On the other hand, satisfaction levels were expressed low. The reasons for this were the increases in the prices of input elements over the years and the volatility of the product price. There were high amounts of input usage levels. In this respect, producers should be made more conscious about input usage, time, amount and application method.

Significance and Impact of the Study: The limited studies on the technical characteristics of pear production increase the originality of this study. Various technical applications of farmers have been presented to the relevant researchers. In this respect, it will also provide an idea about where the improvements in technical structure should be in pear production.
\end{abstract}




\section{GíRiş}

Türkiye gerek iklim koşulları gerekse coğrafi konumu sebebiyle pek çok meyve türünün anavatanı konumundadır. Armutta bu meyvelerden birdir. Dünya'da ilk kez Yunanistan'da yetiştirilmeye başlanan armudun tarihi M.Ö 1000 'li yıllara dayanmaktadır. Avrupa'da; Fransa'da 9. yüzyıldan, Belçika'da ise 13. yüzyıldan itibaren armut yetiştirme çalışmaları yapılmaya başlanmıştır. 19. yüzyıldan itibaren ise Ingiltere' de armut yetiştiriciliği ileri düzeylere ulaşmıştır. Amerika kıtasında ise armut yetiştiriciliğine 1630 yılında İngiliz ve Fransız koloniler tarafından götürülmesiyle başlanılmıştır. Armudun ana vatanı ise Anadolu, OrtaDoğu Avrupa, Kafkasya ve Orta Asya'dır (MEGEP, 2009). Türkiye'de tüketim amaçlı yetiştirilen armut türü Pyrus communis olmakla beraber 600'e yakın türü bulunmaktadır (Davis, 1972; Özçağıran vd., 2004). Armudun dünyada yaklaşık 30 türü vardır. 7-8 metreye kadar büyüyebilen armut ağacının paçasız, yalın biçimli yeşil yapraklarının kenarları çok ince dişlidir. Armut kendine özgü biçimiyle ince kabuklu, yumuşak çekirdekli, eti bol sulu ve lezzetli bir meyvedir (MEGEP, 2009). Türkiye toplam üretimi yaklaşık 519451 ton civarında olan armut özellikle İç Anadolu, Ege Bölgesi ve Güney Marmara bölümünde yaygın bir biçimde yetitştirilmektedir. Armut ılıman iklim koşullarına ihtiyacı olması ve toprak bakımından fazla seçici olmaması sebebiyle Türkiye'de en çok Marmara bölgesinde Bursa ili ve çevresinde yetiştirilmektedir. Bu bölgedeki üretim Türkiye üretiminin $\% 20$ 'sini karşılamaktadır. Üretimin yoğun olarak yapıldığı ikinci alan ise Göller yöresi ve Akdeniz bölgesidir. Akdeniz bölgesinde armut yetiştiriciliği yoğun olarak Antalya ilinde yapılmaktadır. Antalya ili Türkiye'deki armut üretiminin \%12.50'sini karşılamaktadır. Antalya ilinin ilçeleri arasında \% 89.56 üretim oranı ile Korkuteli ilçesi ilk sırada yer almaktadır. Korkuteli ilçesi aynı zamanda Türkiye armut üretiminin \%11.19'unu karşılamaktadır. Korkuteli ilçesi uygun iklim şartları ve uygun toprak yapısı bakımından armut yetiştiriciliğine oldukça elverişli bir bölgedir. Bu özelliklerinden dolayı bu bölge çalışmanın araştırma sahasını oluşturmaktadır. Korkuteli ilçesinde en fazla yetiştiriciliği yapılan armut çeşidi Korkuteli Karyağdı armudu ve Margarit çeşididir. Armut üretiminin teknik özellikleri ilgili çalışmaların oldukça sınırlı olması sebebiyle bu çalışmada Antalya ili Korkuteli ilçesinde armut üretim faaliyeti yapan tarım işletmelerinin teknik özellikleri incelenmiş olup, ilgili araştırmacıların çiftçilerin çeşitli teknik uygulamaları ve armut üretiminde teknik yapıdaki iyileştirmelerin hangi noktalarda olması gerektiği konusunda fikir sağlayabilecektir.

\section{MATERYAL ve YÖNTEM}

Bu çalışmanın ana materyalini, Antalya ili Korkuteli ilçesinde armut yetiştiriciliği yapan işletmelerden anket yöntemi ile elde edilen veriler oluşturmuştur. Analiz için gerekli veriler, Korkuteli'nde armut yetiştiriciliği alanında faaliyet gösteren her bir armut üreticisinden, aracılardan ve işletmelerden yüz yüze anket yoluyla elde edilmiştir. . Çalışmadaki anket formunda, açık uçlu, kapalı uçlu, iki seçenekli, çok seçenekli ile beşli likert ölçekli sorular yer almıştır. Çalışma ile ilgili ikincil veriler ise FAO, TUiK, Tarım ve Orman Bakanlığı il ve illçe müdürlüklerinden temin edilmiştir. Ayrıca konuyla ilgili olarak ulusal ve uluslararası alanda yapılan araştırmalardan da yararlanılmıştır. Araştırmada kullanılan veriler 2018 üretim dönemine aittir.

Anket uygulanan örnek sayısının belirlenmesinde tabakalı örnekleme yöntemlerinden Neyman Yöntemi kullanılmıştır (Yamane, 2001). Armut üretiminde bulunan işletmeler, dikili alan büyüklüğü dikkate alınarak, frekans dağılımına göre dört tabakaya ayrılmıştır. Antalya ili Korkuteli ilçesinde armut dikili alanları 2017 yılı dikkate alınarak 96 işletme olarak hesaplanmıştır. İşletmelerde doldurulan anketler ayrı ayrı gözden geçirilerek, gerekli hesaplamalar yapılmıştır. Daha sonra veri tabanına aktarılan birincil veriler, elektronik ortamda çeşitli istatistik yazılımları kullanılarak gerekli hesaplamalar yapılmış ve çizelgeler oluşturulmuştur.

\section{BULGULAR ve TARTISSMA}

\section{Üreticilerin yaşı, eğitim durumu ve armut yetiştiriciliğindeki deneyimi}

İşletme genişlik gruplarına göre üreticilerin eğitim sürelerinin otalama $3.60 \mathrm{yıl}$, yaş ortalamasının $48.91 \mathrm{yıl}$ olduğu tespit edilmiştir. Bitkisel üretimle uğraşma sürelerinin 27.75 yıl olup, armut deneyim sürelerinin ise 22.93 yıl olduğu tespit edilmiştir (Çizelge 1). İşletme genişlik grupları ile üreticilerin eğitim süreleri, yaş, bitkisel üretimle uğraşma ve armut üretimi ile uğraşma süreleri arasında istatistiki olarak bir ilişki bulunmamaktadır. Görüşülen üreticilerinin \%97.92'sinin armut yetiştiriciliği konusunda eğitim almadıkları, \%2.08'inin eğitim aldıkları belirlenmiştir (Çizelge 2). Üreticiler tarımsal faaliyet konusunda; Tarım ve Orman Bakanlığı il ve ilçe müdürlüklerinden eğitim aldıklarını belirtmişlerdir. 
Çizelge 1. Üreticilerin yaşı, eğitim durumu ve armut yetiştiriciliğindeki deneyimi

Table 1. Age, education level and experience of breeders in pear cultivation

\begin{tabular}{|ccccc|}
\hline $\begin{array}{c}\text { İşletme } \\
\text { genişlik } \\
\text { grupları }\end{array}$ & $\begin{array}{c}\text { Eğitim } \\
\text { (yıl) }\end{array}$ & $\begin{array}{c}\text { Yaş } \\
\text { (yıl) }\end{array}$ & $\begin{array}{c}\text { Bitkisel } \\
\text { üretim } \\
\text { (yıl) }\end{array}$ & $\begin{array}{c}\text { Armut } \\
\text { üretimi } \\
\text { (yıl) }\end{array}$ \\
\hline I & 3.20 & 51.98 & 30.20 & 26.06 \\
\hline II & 4.17 & 43.52 & 22.78 & 18.04 \\
\hline III & 3.62 & 48.77 & 26.23 & 18.23 \\
\hline IV & 4.18 & 46.64 & 29.00 & 24.73 \\
\hline IO & 3.60 & 48.91 & 27.75 & 22.93 \\
\hline AO & 3.50 & 49.51 & 28.08 & 23.53 \\
\hline
\end{tabular}

iO: Görüşülen işletmeler ortalaması

AO: Ağırlıklı ortalama

Çizelge 2. İşletmecilerin tarımsal faaliyet konusunda eğitim alma durumu

Table 2. Training status of the farmers on agricultural activity

\begin{tabular}{|ccccccc|}
\hline $\begin{array}{c}\text { İşletme } \\
\text { genişlik } \\
\text { grupları }\end{array}$ & \multicolumn{2}{c}{$\begin{array}{c}\text { Eğitim } \\
\text { Almayan }\end{array}$} & \multicolumn{2}{c}{$\begin{array}{c}\text { Eğitim } \\
\text { Alan }\end{array}$} & \multicolumn{2}{c|}{ Toplam } \\
\cline { 2 - 7 } & $\mathrm{N}$ & $\%$ & $\mathrm{~N}$ & $\%$ & $\mathrm{~N}$ & $\%$ \\
\hline I & 49 & 100.00 & 0 & 0.00 & 49 & 100 \\
\hline II & 22 & 95.65 & 1 & 4.35 & 23 & 100 \\
\hline III & 12 & 92.31 & 1 & 7.69 & 13 & 100 \\
\hline IV & 11 & 100.00 & 0 & 0.00 & 11 & 100 \\
\hline Toplam & 94 & 97.92 & 2 & 2.08 & 96 & 100 \\
\hline
\end{tabular}

\section{Üreticilerin işletmede kayıt tutma yaklaşımları}

Bütün işletmelerde olduğu gibi tarım işletmelerinin de fiziksel ve finansal durumu ile ilgili bilgiler edinip, sağlıklı kararlar alabilmek, faaliyetlerini sağlıklı bir şekilde sürdürebilmek ve uzun vadede geçerli olabilecek planlamalar yapabilmek için çeşitli muhasebe kayıtlarına ihtiyaç vardır.

Görüşülen üreticilerin \%33.33'ünün düzenli olarak kayıt tuttukları, \%66.67'si ise kayıt tutmadıkları belirlenmiştir. Düzenli olarak en fazla kayıt tutan üreticilerin \%63.34 oran ile dördüncü grupta yer aldıkları belirlenmiştir (Çizelge 3). Görüşüle üreticilerin \%46.88'inin gelir gider durumlarını kontrol edebilmek için kayıt tuttukları belirlenmiştir.

Çizelge 5. Üreticilerin yetiştiriciliğe devam etme eğilimleri Table 5. Producers' tendency to continue growing

\begin{tabular}{|ccccccc|}
\hline $\begin{array}{c}\text { İşletme genişlik } \\
\text { grupları }\end{array}$ & Kesinlikle düşünmüyor & Düşünmüyor & Kararsız & Düşünüyor & Kesinlikle düşünüyor & Toplam \\
\cline { 2 - 7 } & \multicolumn{5}{c|}{ Oran (\%) } \\
\hline I & 8.16 & 2.04 & 0.00 & 89.80 & 0.00 & 100 \\
\hline II & 0.00 & 13.04 & 8.70 & 69.57 & 100 \\
\hline III & 7.69 & 0.00 & 0.00 & 84.62 & 7.69 & 100 \\
\hline IV & 0.00 & 18.18 & 9.09 & 72.73 & 0.00 & 100 \\
\hline Toplam & 5.21 & 6.25 & 3.13 & 82.29 & 13.13 \\
\hline
\end{tabular}

Çizelge 3. Üreticilerin kayıt tutma durumu Table 3. Record keeping status of producers

\begin{tabular}{|ccccccc|}
\hline $\begin{array}{c}\text { İşletme } \\
\text { genişlik } \\
\text { grupları }\end{array}$ & \multicolumn{2}{c}{$\begin{array}{c}\text { Kayıt } \\
\text { tutan }\end{array}$} & \multicolumn{2}{c}{$\begin{array}{c}\text { Kayıt } \\
\text { tutmayan }\end{array}$} & \multicolumn{2}{c|}{ Toplam } \\
\cline { 2 - 8 } & $\mathrm{N}$ & $\%$ & $\mathrm{~N}$ & $\%$ & $\mathrm{~N}$ & $\%$ \\
\hline I & 10 & 20.41 & 39 & 79.59 & 49 & 100 \\
\hline II & 9 & 39.13 & 14 & 60.87 & 23 & 100 \\
\hline III & 6 & 46.15 & 7 & 53.85 & 13 & 100 \\
\hline IV & 7 & 63.64 & 4 & 36.36 & 11 & 100 \\
\hline Toplam & 32 & 33.33 & 64 & 66.67 & 96 & 100 \\
\hline
\end{tabular}

\section{Üreticilerin memnuniyet düzeyleri}

Üreticilerin \%74.04'ünün yetiştiricilikten memnuniyet düzeylerinin çok düşük seviyede, \%18.75'inin düşük seviyede ve \%5.21'inin orta seviyede olduğunu belirlenmiştir. Görüşülen işletmelerde yetiştiricilikten memnuniyet düzeyleri yüksek ve çok yüksek seviyede olan üretici bulunmamaktadır (Çizelge 4).

Işletme genişlik grupları ile üreticilerin memnuniyet düzeyleri arasında istatistiki bir ilişki bulunmamaktadır $(P<0.05)$. Dolayısıyla armut alanı ile memnuniyet düzeyleri arasında biri ilişki bulunmamaktadır.

Çizelge 4. Üreticilerin yetiştiricilikten memnuniyet düzeyleri

Table 4. Farmers' satisfaction levels from cultivation

\begin{tabular}{|ccccc|}
\hline \multirow{2}{*}{$\begin{array}{c}\text { İşletme genişlik } \\
\text { grupları }\end{array}$} & $\begin{array}{c}\text { Çok } \\
\text { düşük }\end{array}$ & Düşük & Orta & Toplam \\
\cline { 2 - 5 } & \multicolumn{4}{c|}{ Oran (\%) } \\
\hline I & 85.71 & 12.24 & 2.04 & 100.00 \\
\hline II & 78.26 & 17.39 & 4.35 & 100.00 \\
\hline III & 30.77 & 46.15 & 23.08 & 100.00 \\
\hline IV & 81.82 & 18.18 & 0.00 & 100.00 \\
\hline Toplam & 76.04 & 18.75 & 5.21 & 100.00 \\
\hline
\end{tabular}

Üreticilerin \%5.21'inin yetiştiriciliğe devam etmeyi kesinlikle düşünmediği, \%6.25'inin düşündüğü, \%3.13'ünün kararsız oldukları, \%82.29'unun yetiştiriciliğe devam etmeyi düşündükleri ve \%3.13'ünün ise yetiştiriciliğe kesinlikle devam etmeyi düşündükleri saptanmıştır (Çizelge 5). İşletme genişlik grupları ile üreticilerin yetiştiriciliğe devam etme durumları arasında istatistiki bir ilişki bulunmamaktadır $(\mathrm{P}<0.05)$. 
Görüşülen üreticilerin $\% 2.08$ 'inin yetiştiricilik konusundaki bilgi düzeylerinin çok düşük seviyede, \%3.13'ünün bilgi düzeylerinin orta seviyede, \%39.58'inin bilgi düzeylerinin yüksek olduğu ve $\% 55.21$ 'inin bilgi düzeylerinin çok yüksek olduklarını belirlenmiştir (Çizelge 6).

Çizelge 6. Üreticilerin yetiştiricilik konusundaki bilgi düzeyleri

Table 6. Knowledge level of producers on growing

\begin{tabular}{|ccccccc|}
\hline \multirow{2}{*}{$\begin{array}{c}\text { Işletme genişlik } \\
\text { grupları }\end{array}$} & Çok düşük & Düşük & Orta & Yüksek & Çok yüksek & Toplam \\
\cline { 2 - 7 } & \multicolumn{7}{c}{ Oran (\%) } & & & \\
\hline I & 2.04 & 0.00 & 0.00 & 46.94 & 51.02 & 100 \\
\hline II & 4.35 & 0.00 & 4.35 & 34.78 & 56.52 & 100 \\
\hline III & 0.00 & 0.00 & 15.38 & 0.00 & 84.62 & 100 \\
\hline IV & 0.00 & 0.00 & 0.00 & 63.64 & 36.36 & 100 \\
\hline Toplam & 2.08 & 0.00 & 3.13 & 39.58 & 55.21 & 100 \\
\hline
\end{tabular}

Çalışma kapsamında görüşülen üreticilerin \%10.42'si düzenli olarak toprak analizi yaptırdıklarını belirtirken, \%89.58'i toprak analizi yaptırmadıklarını belirtmişlerdir. Büyük ölçekli işletmelerde toprak analizi yaptırma oranı \%15'lerin üzerine çıkmaktadır (Şekil 1).

İşletme grupları içerisinde düzenli olarak en fazla toprak analizi yaptıran üreticilerin \%18.18 oran ile dördüncü grupta yer aldıkları belirlenmiştir. İşletme genişlik grupları ile üreticilerin toprak analiz yaptırmaları arasında doğru yönlü bir ilişki bulunmaktadır. İşletme genişlikleri arttıkça üreticilerin toprak analizi yaptırma oranları artmaktadır (Şekil 1).

\section{Toprak analizi yaptıran}

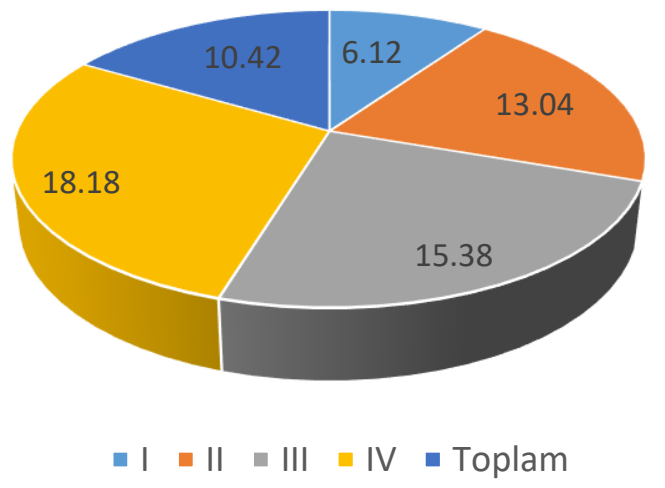

Şekil 1. Toprak analizi yaptıran üreticiler

Figure 1. Producers who have soil analysis done

\section{Armut Yetiştiriciliğinin Teknik Yapısı}

Çalışmanın yapıldığı bölgede görüşülen üreticilerin \%93.75'i yetiştiricilik sisteminin klasik olduğunu belirtirken, \%6.25'i yetiştiricilik sisteminin modern olduğunu belirtmişlerdir.

İsletme gruplarına göre en fazla klasik usulde yetiştiricilik yapan üreticiler \%100 oran ile ikinci grupta yer alırken, en fazla modern usulde yetiştiriciliği yapan üreticiler \%23.08 oran ile dördüncü grupta yer almaktadır (Çizelge 7). İşletme genişlikleri ile yetiştiricilik sistemi arasında istatistiki bir ilişki bulunmamaktadır.

Çizelge 7. Armut işletmelerinde yetiştiricilik sistemi Table 7. Pear farms cultivation system

\begin{tabular}{|ccccccc|}
\hline $\begin{array}{c}\text { İşletme } \\
\text { genişlik } \\
\text { grupları }\end{array}$ & \multicolumn{2}{c}{ Klasik } & \multicolumn{2}{c}{ Modern } & \multicolumn{2}{c|}{ Toplam } \\
\hline I & 47 & 95.92 & 2 & 4.08 & 49 & 100 \\
\hline II & 23 & 100 & 0 & 0.00 & 23 & 100 \\
\hline III & 10 & 76.92 & 3 & 23.08 & 13 & 100 \\
\hline IV & 10 & 90.91 & 1 & 9.09 & 11 & 100 \\
\hline Toplam & 90 & 93.75 & 6 & 6.25 & 96 & 100 \\
\hline
\end{tabular}

\section{Armut üretimine ilişkin bilgileri}

Armut ağaçları genellikle dikine büyüyerek çeşitlerin çoğunda piramit şeklini alırlar. Ağaçlar düzgün, dik ve koyu renkli bir gövdeye sahiptir. Kabuk rengi ve kalınlığı çeşitlere göre değişmekle birlikte genç ağaçlarda düzgün yaşlı ağaçlarda parçalı bir yapıdadır. Kökleri kazık kök şeklinde derinlere kadar iner. Dalları tüysüz olup, odun ve meyve dalı olarak ikiye ayrılır. Meyve dalları kopuz, kargı, dalcık ve çıtanak olarak adlandırılmaktadır. Tomurcukları genellikle bu dallar üzerinde oluşur. Bu tomurcuklar odun ve çiçek tomurcuğu şeklinde ikiye ayrılırlar. Tomurcukların dallar üzerinde yanal olarak bulunmasıyla yapraklar meydana gelir. Armut ağacının yapraklarının büyüklüğü ve şekli çeşitlere göre değişiklik gösterse de, bazıları yuvarlak bazıları da oval yuvarlak şekle sahiptirler. Bir çiçek tomurcuğu açıldığında genellikle 5 ile 7 adet çiçek ve çok sayıda yaprak oluşur. Armut meyvesi yalancı bir meyve olup, meyveni şekli, rengi ve büyüklüğü çeşitlere göre farklılık arz etmektedir (MGEP, 2009).

Armut, elmaya göre soğuk hava şartlarına karşı daha dayanıksızdır. Bu nedenle armut meyvesi ılıman iklim 
şartlarında yetiştirilmeye daha müsaittir. Armut her ne kadar ılıman iklim meyvesi olsa da bazı çeşitleri soğuğa karşı dayanıklıdır. Armut ağaçlarının ılıman iklimde çeşitlerinin birçoğunun düzenli olarak çiçek açabilmesi için kış aylarında dinlenme döneminde 7.2 ․ $C^{\prime}$ nin altında ortalama 1000-1500 saatlik bir sıcaklık toplamına ihtiyaç duyarlar. Soğuklara karşı dayanıklılık gösteren çeşitler ise kış soğuklarında dinlenme döneminde -20 ile -25 oC'ye kadar kısa sürelide olsa dayanabilmektedirler (MEGEP, 2009).

\section{işletmelerde yetiştirilen armut çeşitleri}

Armut tohumdan, çelikle ve aşı ile üretilir. Armut yetiştiricileri ayva anacına yapılan aşılarla meyvelerin daha büyük olması sebebiyle genellikle anaç olarak ayvayı tercih etmektedirler. Ayva anacının kullanılmasının tek dezavantajı ömrünün az olmasıdır. Armut yetiştiriciliğinde ayva anacından sonra aşılamada en çok tercih edilen anaç armut çöğürüdür. Bu anacın ağacı daha büyük ve uzun ömürlü olduğu için standart armut bahçesi yapmak için genellikle bu anaç tercih edilir (MEGEP, 2009).

Araştırma bölgesinde üreticilerin armut yetiştiriciliğinde ağaçların aşılanmasında genellikle BA_29 ve Quince $A$ ayva anacı ile OHF_333 ve OHF 87 armut çöğür anacını kullandıkları belirlenmiştir. Araştırma bölgesinde görüşülen üreticiler hem kışlık, hem güz armudu hem de yazlık armut çeşitlerin yetiştirebilmektedir. Araştırma bölgesinde görüşülen üreticilerin çoğunluğu uygun iklim koşulları ve toprak yapısı sebebiyle Margarit ve Korkuteli Karyağdı armudu çeşidini yetiştirmekte olduklarını belirtmişlerdir. Margarit armut çeşidi daha çok Kiefer armudu olarak bilinmektedir. Ağaçları yarı dik olup, çok hızlı gelişir. Meyveleri iri, sap ve çiçek kesimi dar, orta kesimi şişkincedir. Meyvesi yeşil sarımtırak bir renktedir. Meyve eti beyaz, sulu, sert ve kumlu bir yapısı vardır. Hastalıklara karşı oldukça dayanıklıdır. Soğuk hava depolarında uzun süre saklanmaya elverişlidir. Eylül ortası- ekim başı civarında hasat edilmeye başlanır (MEGEP, 2009).

Karyağdı armudu Korkuteli ilçesine özgü coğrafi işaretli bir çeşittir. Ağacı; dikine büyüyen, ana dalları seyrek, yan dalları sık, gövdesi ve dalları siyaha yakın koyu gri renklidir. Bu çeşidin ağaçları kullanılan anaç çeşidine göre farklı düzeylerde gelişmektedir. Yapraklarının kenarları fark edilemeyecek kadar yayvan, basit dişli, olup, yaprak sapı ise uzun, sarımtırak yeşil renkte ve tüysüz bir yapıya sahiptir. Çiçek sapı düzgün, yeşil renkli olup, meyve sapı orta kalınlıkta ve kısa, meyve kabuğu ince, yumuşak, az pürüzlü, mumsuz, az parlak ve kabuk rengi hasattan önce ot yeşili, hasat zamanı parlak yeşil, olgunlaşmaya yakın koyu yeşil, yeme olgunluğuna eriştiğinde ise da ise sarımtırak yeşil bir renk almaktadır. Meyve eti krem renkli olup; çok sulu, çok tatlı, kumsuz ve ağızda eriyen bir yapıya sahiptir. Korkuteli Karyağdı Armudunun üretiminde armut meyvesine ilişkin genel üretim teknikleri kullanmasına karşın iklim ve toprak özelliklerine de dikkat edilmelidir. Karyağdı Armudunun yetiştirildiği coğrafi bölge yazları sıcak, bol güneşli, kurak, havadar ve nem oranı düşük iklim koşullarına sahiptir. Bu iklim özelliğinin meyve kalitesi üzerinde önemli bir etkisi vardır. Soğuğa karşı dayanıklı bir tür oluşu uzun süre uzun süre depolanabilmesine olanak sağlamaktadır. Korkuteli Karyağdı Armudunun kalitesine ve özgünlüğüne etki eden en önemli faktörlerin başında toprak yapısı derin, geçirgen, kilsiz ve besin maddelerince zengin olan toprak yapısı etkili iken; verimlilik ve kalite açısından en önemli unsurlar sulama ve gübrelemedir. Bahçe tesis edilirken 1-2 yaş aralığındaki ve çıplak köklü fidanlar tercih edilmeli, dikdörtgen veya kare dikim sisteminin uygulandığı bahçelerde sıra düzeni ve üzeri mesafe kullanılan anaca ve terbiye şekline göre değişmektedir (MAREM,2014; MEGEP, 2009).

Araştırma bölgesinde görüşülen üreticilerin $\% 48.56$ 'sı Korkuteli Karyağdı armudu, \%28.13'ü ise Margarit çeşidi yetiştirmektedir. Margarit çeşidinden çeşitlerinden sonra en fazla Williams ve Santa Maria armut çeşitlerini yetiştirmektedir. Bölgedeki yetiştiricilerin \%7.29'u Williams, \%6.25'i ise Santa Maria çeşidini yetiştirmektedir. İşletme gruplarına göre; en fazla Korkuteli Karyağdı armudu çeşidi (\%55.81) ve margarit çeşidi (\%30.23) yetiştiren üreticilerin birinci grupta yer aldıkları belirlenmiştir (Çizelge 8).

Çizelge 8. Alana göre yetiştirilen armut çeşitleri (\%) Table 8. Pear varieties of farms by area (\%)

\begin{tabular}{|lccccc|}
\hline \multirow{2}{*}{ Çeşitler } & \multicolumn{5}{c|}{ İşletme genişlik grupları } \\
\cline { 2 - 6 } & I & II & III & IV & Toplam \\
\hline Ankara & 0.00 & 7.69 & 0.00 & 10.00 & 3.13 \\
\hline Deveci & 2.33 & 0.00 & 5.88 & 0.00 & 2.08 \\
\hline Santa Maria & 4.65 & 0.00 & 17.65 & 10.00 & 6.25 \\
\hline Akça & 2.33 & 0.00 & 0.00 & 0.00 & 1.04 \\
\hline June Beauty & 0.00 & 0.00 & 5.88 & 0.00 & 1.04 \\
\hline Williams & 4.65 & 15.38 & 5.88 & 0.00 & 7.29 \\
\hline Limon & 0.00 & 0.00 & 11.76 & 0.00 & 2.08 \\
\hline Margarit & 30.23 & 26.92 & 23.53 & 30.00 & 28.13 \\
\hline Karyağdı & 55.81 & 50.00 & 29.41 & 50.00 & 48.96 \\
\hline Toplam & 100 & 100 & 100 & 100 & 100 \\
\hline
\end{tabular}

\section{Armut ağaç sayısı}

İ̧letme genişlik gruplarına göre birim alan düşen armut ağacı sayısı da farklılık göstermektedir. Çalışmanın yapıldığı bölgede dekara ortalama ağaç sayısı 823.63 adettir. Bölgede üreticiler tarafından en fazla yetiştirilen 
çeşitlerden Karyağdı armudu ağaç sayısının dekara 493.59 adet, Margarit armut ağaç sayısının dekara 277.49 adet olduğu tespit edilmiştir (Çizelge 9).

İşletme genişlik gruplarına göre; işletmelerin ortalama \%55.93'ünü Karyağdı armut ağaçlarının oluşturduğu, \%33.69'unu ise Margarit çeşidi armut ağaçlarının oluşturduğu saptanmıştır (Çizelge 9)

Erbaşlar (2014), çalışmasında dekar başına ortalama ağaç sayısının; Deveci armudunda 37.65 adet, Santa Maria 35.93 adet olduğunu belirtmiştir.

Çizelge 9. Armut ağaç sayısı

Table 9. Tree numbers of pear producers

\begin{tabular}{|lcccccc|}
\hline \multirow{2}{*}{ Çeşitler } & \multicolumn{7}{c|}{ işletme genişlik grupları } \\
\cline { 2 - 7 } & I & II & II & IV & iO & AO \\
\cline { 2 - 7 } & & \multicolumn{7}{c|}{ Oran (\%) } & & & \\
\hline Ankara & 0.00 & 5.34 & 0.76 & 0.00 & 0.97 & 1.42 \\
\hline Deveci & 0.41 & 0.00 & 0.88 & 0.00 & 0.23 & 0.28 \\
\hline Santa Maria & 5.41 & 0.00 & 1.91 & 0.96 & 1.92 & 2.72 \\
\hline Akça & 1.71 & 0.00 & 0.00 & 0.00 & 0.37 & 0.72 \\
\hline June Beauty & 0.00 & 0.00 & 0.91 & 0.00 & 0.15 & 0.12 \\
\hline Williams & 4.41 & 6.77 & 3.05 & 0.00 & 2.53 & 3.93 \\
\hline Limon & 0.00 & 0.64 & 0.61 & 0.00 & 0.20 & 0.08 \\
\hline Margarit & 35.07 & 45.10 & 20.05 & 34.03 & 33.69 & 35.52 \\
\hline Karyağdı & 52.99 & 42.15 & 71.83 & 65.01 & 59.93 & 55.20 \\
\hline Toplam & 100 & 100 & 100 & 100 & 100 & 100 \\
\hline
\end{tabular}

\section{Işgücü ve makine gücü kullanımı}

İşletme genişlik gruplarına göre birim alanda kullanılan işgücü ve makine gücü farklılık göstermektedir. Görüşülen armut işletmelerinde dekar başına kullanılan aile işgücünün işletmeler ortalaması 18.68 saat, yabancı işgücünün işletmeler ortalaması dekar başına 55.71 saat olup toplam işgücü ortalaması dekar başına 74.39 saattir. Dekar başına kullanılan ortalama makine gücü ise 2.81 saattir (Çizelge 10).

İ̧letme gruplarına göre; en fazla aile işgücü kullanım oranı \%58.48 ile birinci grup işletmelere aittir. En fazla yabancı işgücü kullanım oranı ise $\% 86.82$ ile dördüncü gruba ait olduğu tespit edilmiştir (Çizelge 10).

Çizelge 10. Armut üretiminde işgücü ve makine gücü kullanımı

Table 10. Use of manpower and machine power in pear production

\begin{tabular}{|c|c|c|c|c|c|c|}
\hline & \multicolumn{6}{|c|}{ İşletme genişlik grupları } \\
\hline & $\mathrm{I}$ & II & III & IV & io & $\mathrm{AO}$ \\
\hline & \multicolumn{6}{|c|}{ Birim alana kullanım (da) } \\
\hline Aile işgücü (saat) & 50.83 & 24.78 & 15.52 & 8.19 & 18.68 & 27.68 \\
\hline Yabancı işgücü (saat) & 36.10 & 74.59 & 59.07 & 53.95 & 55.71 & 54.96 \\
\hline Toplam işgücü (saat) & 86.93 & 99.36 & 74.60 & 62.14 & 74.39 & 82.64 \\
\hline \multirow{2}{*}{ Toplam makine gücü (saat) } & 4.96 & 3.29 & 2.31 & 2.19 & 2.81 & 3.41 \\
\hline & \multicolumn{6}{|c|}{ Oran (\%) } \\
\hline Aile işgücü & 58.48 & 24.93 & 20.81 & 13.18 & 25.11 & 33.49 \\
\hline Yabancı işgücü & 41.52 & 75.07 & 79.19 & 86.82 & 74.89 & 66.51 \\
\hline Toplam işgücü & 100 & 100 & 100 & 100 & 100 & 100 \\
\hline
\end{tabular}

\section{Kültürel İşlemler}

\section{işletmelerde toprak işlemesi}

Toprak işleme meyve bahçelerinde, toprağı havalandırmak, toprağın yüzeyinde yağmurlardan ve sulamalardan meydana gelen kaymak tabakasını kırarak buharlaşmasını sağlamak, yabancı otları yok etmek ve toprakta bulunan besin maddelerinin parçalanarak bitkilerin isine yarar duruma gelmelerini sağlaması bakımından önemli bir işlem olarak ifade edilebilir (MEGEP, 2009; MAREM, 2014).

Armut ağaçları genellikle toprak bakımından fazla seçici olmamasına rağmen toprağın derin, geçirgen ve besin maddelerince zengin oluşu ağaçların gelişimi ve verimi açısından oldukça önemlidir. Kullanılan anaç türüne göre de toprak isteğinde değişiklik görülebilir. Kuru, sığ ve taşlı topraklarda ağaçların meyveleri kumlu ve şekilleri bozuk olur. Nemli topraklarda armutların meyve eti kaba ve 
yavan olup, bu toprak yapısında kışlık armutlar iyi olgunlaşamaz. Bu durumda meyvelerin depolarda muhafaza süresini azaltır(MEGEP, 2009; MAREM, 2014). Armut ağacı yüksek oranda organik maddeye intiyaç duyduğundan organik madde bakımından zayıf olan topraklar iyi yanmış ahır gübresi ile gübrelenmelidir. Su ve rüzgâr erozyonunun yoğun olduğu coğrafyalarda armut bahçelerinde devamlı veya geçici örtülü toprak işleme yöntemi uygulanır. Bu şekilde toprağın taşınması önlenmiş olur. Erozyon tehlikesinin bulunduğu ve yağışın yeterli olmadığı kesimlerde toprak yıl içerisinde dört farklı dönemde işlenerek yabancı otlardan arındırılarak ve havalandırıması sağlanır. Yaz mevsiminde bahçelerde yabancı otlar tekrar oluşur. Bu durumda sürüm işlemi yinelenirse sulama sistemi bozulabilir. Böyle bir durumda bu işlemlerin tekrarlanması gereklidir. Eğer damla sulama sistemi kullanılıyor ise; boruların kaldırılması ve sürümden sonra sulama düzeninin tekrar kurulması gereklidir. Armut bahçelerinde düzenli toprak işlemesi, değişik alet ve makinaların kullanımıyla tüm yıl boyunca bahçede yabancı ot çıkışına müsaade edilmez (MEGEP, 2009; MAREM, 2014). Görüşülen üreticilerin ortalama \%96.88'inin düzenli olarak toprak işlemesi yaptıkları belirlenmiştir. Birinci ve üçüncü grup işletmelerde üreticilerin tamamının düzenli olarak toprak işlemesi yapmakta olduğu tespit edilmiş olup, ikinci gruptaki üreticilerin \%95.65'nini ve üçüncü gruptaki üreticilerin $\% 81.82$ 'sinin düzenli olarak toprak işleme yaptırdıkları tespit edilmiştir(Şekil 2).

Görüşülen üreticilerin \%3.13'ünün düzenli olarak toprak işlemesi yapmadıkları belirlenmiştir.

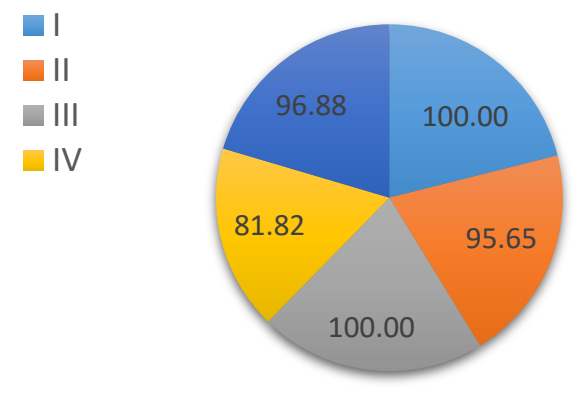

Şekil 2. Toprak işlemesi yaptıran üreticiler

Figure 2. Producers who have soil cultivation done

\section{Armut üretiminde sulama miktarı}

Ağaçların sağlıklı gelişmesi, düzenli ürün verimi ve kaliteli meyve elde edebilmesi için sulamanın mutlaka düzenli yapılması gerekmektedir. Sulama sırasında aşırı sudan ve sulama suyunun ağacın gövdesine değmesinden kaçınılmalıdır. Armut bahçesinin durumu, ağaçların dikim sırası ve şekli, armut çeşitleri ve toprağın yapısına göre damla sulama veya mini-yağmurlama sistemleri kullanılabilir. Ayva klonu aşılanan bahçelerde, diğer anaçların kullanıldığı bahçelere göre daha fazla oranda sulama yapılmalıdır. Anaç çeşitlerine göre sulama yapılırken; ayvadan sonra armut, ahlat ve alıç azalan miktarlarda sulanmalıdır (MEGEP, 2009). Araştırma bölgesine görüşülen üreticiler sezon boyunca ortalama 18.43 sefer sulama yaptıklarını ve dekar başına ortalama 414.08 ton su kullandıklarını belirtmişlerdir. Araştırma bölge ortalamasında ise sulama sayısının $18.77 \mathrm{kez}$ olduğu ve dekar başına su kullanımının çiftçilerden alınan bilgilerden hareketle 477.27 ton olduğu tespit edilmiştir.

İşletme genişlik gruplarına göre sezon boyunca sulama sayılarının 13.75 ile 20.26 defa arasında değiştiği belirlenmiştir (Şekil 3).

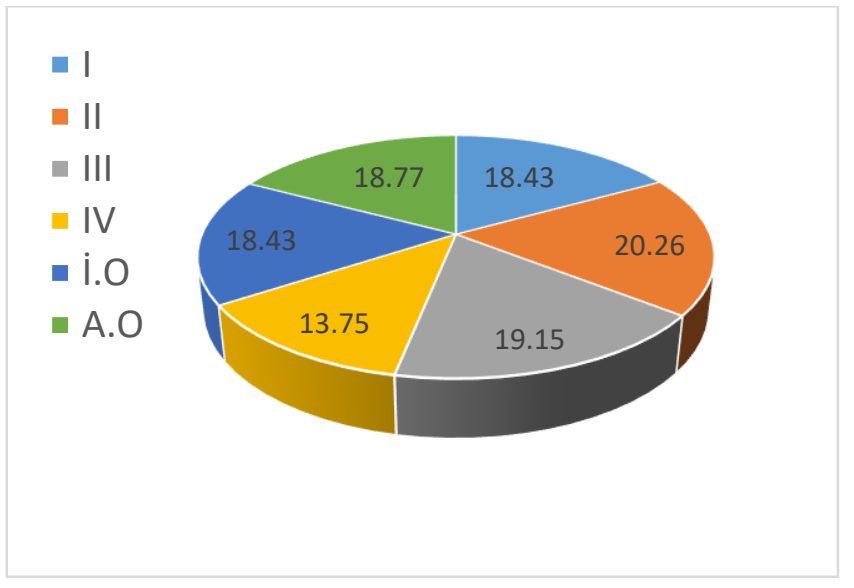

Şekil 3. Armut yetiştiriciliğinde sulama sayısı

Figure 3. Number of irrigation in pear cultivation

\section{Armut üretiminde sulama sistemi}

Araştırma bölgesinde görüşülen armut üreticilerinin ortalama \%88.54'ünün damla sulama sistemini ve \%14.29'unun salma sulama sistemini kullandıkları belirlenmiştir (Çizelge 11).

Çizelge 11. Armut işletmelerinde sulama sistemi Table 11. Irrigation system in pear farms

\begin{tabular}{|ccccccc|}
\hline & \multicolumn{7}{c|}{ işletme geniş̧lik grupları } \\
\cline { 2 - 7 } & I & II & III & IV & i.O & A.O \\
\hline \multicolumn{7}{c}{ Oran (\%) } \\
\hline Damla & 85.71 & 86.96 & 92.31 & 100 & 88.54 & 86.04 \\
\hline Salma & 14.29 & 13.04 & 7.69 & 0.00 & 11.46 & 13.96 \\
\hline Toplam & 100 & 100 & 100 & 100 & 100 & 100 \\
\hline
\end{tabular}

Işletme gruplarına göre; dördüncü grupta yer alan üreticilerin tamamı damla sulama sistemini kullandıkları 
belirlenmiştir. Salma sulama sistemini en fazla kullanan üreticiler \%14.29 oran ile birinci grupta yer aldıkları belirlenmiştir.

\section{Armut işletmelerinde budama}

Ağaçların meyve veriminin düşmemesi ve kalitenin etkilenmemesi için düzenli budama yapılması çok önemlidir. Meyve ağırlıklarından dolayı dal kırılmalarının önlenmesi için hereklerle destekler yapılmalıdır Armut yetiştiriciliğinde budama armut fidanın alınması ile başlar. Bu sebeple ağaçlarda kullanılacak olan budama şekilleri; anaç türüne, armut çeşidinin büyüme gücüne, şekline, bahçe yerine, toprak tipine, çeşidin meyve iriliğine ve uygulanacak olan kültürel işlemeler göre değişiklik göstermektedir. Armut ağaçlarında çoğunlukla dikine büyüme eğilimi olduğundan dike yakın olan budama şekillerinin verilmesi ve uygulaması daha kolay ve uygundur(MEGEP, 2009).

Üreticilerin \%91.67'sinin budama işlemi yaparken özel bir şekil verdikleri, \%8.33'ünün budama işlemi yaparken özel bir şekil vermediklerini belirlenmiştir. İşletme gruplarında armut ağaçını budar iken özel şekil verme oranı \%90.91 ila \%92.31 oranında değişmektedir.

Üreticilerin ortalama \%51.04'ünün doruk dal, \%35.42'sinin goble, \%10.42'sinin kordon, \%2.08'inin değişik dorukdal, \%1.04'ünün palmet budama şekillerini tercih ettikleri tespit edilmiştir (Çizelge 12).

Birinci gruptaki üreticilerin \%44.90'ının, üçüncü gruptaki üreticilerin \%46.15'inin ve dördüncü gruptaki üreticilerin $\% 54.55$ 'inin doruk dallı budama şekillerini tercih ettikleri belirlenmiştir. Doruk dallı budama şeklini en fazla tercih eden üretici sayısının ise \%65.22 oran ile ikinci grupta yer aldığı belirlenmiştir (Çizelge 12). Görüşülen üreticilerin tamamı düzenli olarak makinelerle çapalama yaptıklarını ve ilaçlarla yabancı otlarla mücadele ettiklerini belirtmişlerdir.
Çizelge 12. Armut üreticilerinin budamada şekilleri Table 12. Pear growers' pruning shapes

\begin{tabular}{|c|c|c|c|c|c|c|}
\hline & \multicolumn{4}{|c|}{ İşletme genişlik grupları } & \multirow{2}{*}{ io } & \multirow{2}{*}{$\mathrm{AO}$} \\
\hline & I & II & III & IV & & \\
\hline & \multicolumn{6}{|c|}{ Oran (\%) } \\
\hline Doruk dal & 44.90 & 65.22 & 46.15 & 54.55 & 51.04 & 61.60 \\
\hline $\begin{array}{l}\text { Değişik } \\
\text { doruk dal }\end{array}$ & 4.08 & 0.00 & 0.00 & 0.00 & 2.08 & 0.00 \\
\hline Goble (vazo) & 40.82 & 26.09 & 38.46 & 27.27 & 35.42 & 28.21 \\
\hline Kordon & 10.20 & 8.70 & 7.69 & 18.18 & 10.42 & 8.90 \\
\hline Palmet & 0.00 & 0.00 & 7.69 & 0.00 & 1.04 & 1.29 \\
\hline Toplam & 100 & 100 & 100 & 100 & 100 & 100 \\
\hline
\end{tabular}

\section{Armut işletmelerinde gübreleme}

Bütün meyve bahçelerinde olduğu gibi armut bahçelerinde de dengeli ve düzenli bir gübreleme yapılmalıdır. Gübreleme işleminin etkili olması için mutlaka her yıl toprak ve üç yılda bir yaprak analizleri yapılmalıdır. Bu analizlerin sonucunda bahçenin gübre ihtiyacı belirlenmelidir. Armut bahçelerinin gübrelenmesinde çiftlik gübresi, yeşil gübre ve kimyasal gübreler kullanılmaktadır. Çiftlik gübresi içerdiği humus sayesinde toprağın fiziki yapısını düzeltirken, toprağa da en çok ihtiyaç duyduğu besin elementleri olan azot, fosfor ve potasyum elementlerini kazandırır. Kimyasal gübreler, ağaçların taç iz düşümü içerisine, gövde ve köklere temas etmeyecek şekilde uygulanmalıdır. Bitkinin ihtiyacı olan makro elementlerin her yıl, mikro elementlerin ise ihtiyaca göre verilmesi gereklidir. Armutlarda demir ve bor noksanlığına sık rastlanmaktadır (MEGEP, 2009).

Üreticilerin gübre kullanım miktarları incelendiğinde; işletmeler ortalamasında $756.78 \mathrm{~kg}$ azot (N), $587.11 \mathrm{~kg}$ fosfor (P2O5), $166.28 \mathrm{~kg}$ potasyum (K2O) kullanılmıştır. Bölge ortalamasında ise $561.76 \mathrm{~kg}$ azot, $404.03 \mathrm{~kg}$ fosfor, $94.19 \mathrm{~kg}$ potasyum kullandıkları belirlenmiştir.

Çizelge 13. Gübre kullanım miktarları

Table 13. Fertiliser usage amounts

\begin{tabular}{|c|c|c|c|c|c|c|}
\hline \multirow{3}{*}{ Bitki besin } & \multicolumn{6}{|c|}{ İşletme genişlik grupları } \\
\hline & $\mathrm{I}$ & II & III & IV & io & $\mathrm{AO}$ \\
\hline & \multicolumn{6}{|c|}{ İşletme ortalaması (kg) } \\
\hline $\mathrm{N}$ & 349.70 & 800.60 & 890.55 & 2320.36 & 756.78 & 561.76 \\
\hline $\mathrm{P}$ & 265.37 & 450.69 & 732.67 & 2133.55 & 587.11 & 404.03 \\
\hline \multirow[t]{2}{*}{$\mathrm{K}$} & 53.91 & 67.69 & 246.13 & 778.64 & 166.28 & 94.19 \\
\hline & \multicolumn{6}{|c|}{ Dekar başına (kg) } \\
\hline $\mathrm{N}$ & 72.45 & 68.97 & 39.38 & 32.23 & 45.71 & 56.70 \\
\hline $\mathrm{P}$ & 54.98 & 38.82 & 32.40 & 29.63 & 35.46 & 40.78 \\
\hline \multirow[t]{2}{*}{$\mathrm{K}$} & 11.17 & 5.83 & 10.88 & 10.81 & 10.04 & 9.51 \\
\hline & \multicolumn{6}{|c|}{ Ağaç başına (kg) } \\
\hline $\mathrm{N}$ & 1.03 & 1.48 & 0.90 & 0.70 & 0.93 & 1.06 \\
\hline $\mathrm{P}$ & 0.78 & 0.83 & 0.74 & 0.64 & 0.72 & 0.76 \\
\hline $\mathrm{K}$ & 0.16 & 0.12 & 0.25 & 0.24 & 0.20 & 0.18 \\
\hline
\end{tabular}


Birim alana (dekar başına) işletmeler ortalamasında $45.71 \mathrm{~kg}$ azot, $35.46 \mathrm{~kg}$ fosfor ve $10.04 \mathrm{~kg}$ potasyum kullanıldığı, dekar başına bölge ortalamasında ise 56.70 $\mathrm{kg}$ azot, $40.78 \mathrm{~kg}$ fosfor ve $9.51 \mathrm{~kg}$ potasyum kullanıldığı belirlenmiştir. İncelenen işletme gruplarında dekara azot kullanımı 32.23 ile $72.45 \mathrm{~kg}$ arasında değişmektedir. Fosfor kullanımı ise işletme gruplarında 29.63 ile 54.98 kg arasında olduğu hesaplanmıştır. Potasyum kullanımı ise 5.83 ila $11.17 \mathrm{~kg}$ arasında olduğu tespit edilmiştir. Armut üretiminde dekara en fazla azot, fosfor ve potasyum uygulamasının birinci grup işletmelerde olduğu belirlenmiştir (Çizelge 13).

Görüşülen işletmelerin \%27.08'inde çiftlik gübresi uygulaması armut üretiminde olmamıştır. Buna karşın ele alınan işletmelerin \%72.92'si farklı oranlarda da olsa çiftlik gübresi uygulaması armut arazisine yapmıştır. Ele alınan işletmelerin \%23.96'sı da armut üretiminde yaprak gübrelemesi yapmamaktadır. Yaprak gübresi kullanım oranı \%90.91 ile en fazla dördüncü grup işletmelerdedir.

Gürel (2013) çalışmasında toplam azot birinci derinlikte içeriklerinin \%0.05-0.49 arasında olduğunu, ikinci derinlikte \%0.01-0.29 arasında değiştiğini belirtmiştir.

\section{Armut işletmelerinde ilaçlama}

Armut ağaçlarının en çok etkilendiği hastalık ve zararlıların; Armut ateş yanıklığı, külleme, kara leke, monilya, armut testereli arısı, armut göz kurdu, iç kurdu, memeli pas, meyve iç kurdu, armut yaprak piresi, armut sülüğü (psillidi) ve kabuklu bitler olduğu bilinmektedir (MEGEP, 2009). Ancak bölgedeki üreticilerden elde edilen bulgulara göre en yaygın hastalıkların ateş yanıklığı ve kara leke olduğu tespit edilmiştir. En yaygın zararlıların ise; armut testereli arısı, iç kurdu ve armut psillidi olduğu tespit edilmiştir. Araştırma bölgesinde görüşülen üreticilerin tamamı en önemli hastalığın ateş yanıklığı ve en önemli zararlının armut psillidi olduğunu belirtmişlerdir.

Çizelge 14. Armut üreticilerin ilaçlama takvimi kullanma durumu

Table 14. Pear producers' use of spraying schedule

\begin{tabular}{|ccccccc|}
\hline $\begin{array}{c}\text { İşletme } \\
\text { genişlik } \\
\text { grupları }\end{array}$ & $\begin{array}{c}\text { Ilaçlama } \\
\text { takvimi } \\
\text { olan }\end{array}$ & \multicolumn{2}{c}{$\begin{array}{l}\text { Ilaçlama } \\
\text { takvimi } \\
\text { olmayan }\end{array}$} & \multicolumn{2}{l|}{ Toplam } \\
\cline { 2 - 8 } & $\mathrm{N}$ & $\%$ & $\mathrm{~N}$ & $\%$ & $\mathrm{~N}$ & $\%$ \\
\hline I & 45 & 91.84 & 4 & 8.16 & 49 & 100 \\
\hline II & 22 & 95.65 & 1 & 4.35 & 23 & 100 \\
\hline III & 9 & 69.23 & 4 & 30.77 & 13 & 100 \\
\hline IV & 10 & 90.91 & 1 & 9.09 & 11 & 100 \\
\hline Toplam & 86 & 89.58 & 10 & 10.42 & 96 & 100 \\
\hline
\end{tabular}

Araştırma bölgesinde görüşülen üreticilerin \%89.10'uun bir ilaçlama takvimlerinin olduğu ve bu takvime uyarak ilaçlama yaptıkları tespit edilmiştir. Üreticilerin \%10.42'sinin ise ilaçlama takvimlerinin olmadığı tespit edilmiştir. İşletme genişlik gruplarına göre ilaçlama takvimine en çok uyan üreticilerin \%95.65 oranıyla ikinci grupta yer aldıkları, takvime uymayan en fazla üreticilerin \%30.77 oran ile üçüncü grupta yer aldıkları belirlenmiştir (Çizelge 14).

Işsletmelerin kimyasal ilaç türleri içerisinde en çok fungusit ilaçlar kullandığı belirlenmiştir. İşletmeler ortalamasında kullanılan fungusit ilaç miktarı 19575.10 g'dır. Kullanılan insektisit miktarı 6687.50 ve herbisit miktarı ise 2760.52 g'dır. İşletme grupları içerisinde en fazla fungusit kullanan işletmeler (75197.27 g), en fazla insektisit (2404.45 g) ve en fazla herbisit (8681.82 g) kullanan işletmeler ise dördüncü grupta yer almaktadır (Çizelge 15).

İşletmelerde kullanılan dekara ortalama fungusit miktarı $1182.26 \mathrm{gr}$, insektisit miktarı $403.90 \mathrm{gr}$ ve herbisit miktarı ise $166.73 \mathrm{gr}$ olarak hesaplanmıştır. İşletme genişlik grupları içerisinde dekara en fazla fungusit kullanan işletmelerin $1340.27 \mathrm{~g}$ ile üçüncü grupta, en fazla insektisit kullanan işletmelerin $566.60 \mathrm{~g}$ ile birinci grupta ve en fazla herbisit kullanan işletmelerin ise $366.64 \mathrm{~g}$ ile birinci grupta yer aldığı tespit edilmiştir (Çizelge 15).

Çizelge 15. İşletmelerin armut üretiminde kullandıkları ilaç miktarı

Table 15. The amount of agrochemical used by farms in pear production

\begin{tabular}{|c|c|c|c|}
\hline İşletme & Herbisit & Fungusit & Insektisit \\
\hline $\begin{array}{l}\text { genışı|IK } \\
\text { grupları }\end{array}$ & \multicolumn{3}{|c|}{ İşletme ortalaması miktarı (gram) } \\
\hline I & 1769.59 & 6333.67 & 2734.69 \\
\hline II & 1982.61 & 15115.22 & 5043.48 \\
\hline III & 2861.54 & 30310.77 & 9807.69 \\
\hline IV & 8681.82 & 75197.27 & 24045.45 \\
\hline io & 2760.52 & 19575.10 & 6687.50 \\
\hline \multirow[t]{2}{*}{$\mathrm{AO}$} & 2124.15 & 12374.85 & 4480.81 \\
\hline & \multicolumn{3}{|c|}{ Dekara uygulama (gram) } \\
\hline 1 & 366.64 & 1312.26 & 566.60 \\
\hline II & 170.79 & 1302.06 & 434.46 \\
\hline III & 126.53 & 1340.27 & 433.67 \\
\hline IV & 120.58 & 1044.41 & 333.96 \\
\hline io & 166.73 & 1182.26 & 403.90 \\
\hline $\mathrm{AO}$ & 214.40 & 1249.06 & 452.27 \\
\hline
\end{tabular}

Üreticilerin \%96.88'inin kullanılan ilaçların kalıntı bıraktığını, \%3.13'ünün ilaçların kalıntı bırakmadığını belirttikleri tespit edilmiştir. Birinci, ikinci ve dördüncü grupta bulunan üreticilerin hepsinin kullanılan tarım ilaçlarının kalıntı bıraktığını, ikinci grupta bulunan üreticilerin \%76.92'sinin ilaçların kalıntı bırakmadıklarını 
belirttikleri tespit edilmiştir (Çizelge 16). Erbaşlar (2014) çalışmasında üreticilere kullanılan tarım ilaçlarının kalıntısı sorulduğunda \%38.23'ünün kalıntı bırakmadığını, \%23.52'sinin bazı ilaçların kalıntı bırakmadığını, \%20.58'inin ilaçların kalıntı bıraktığını belirtirken, \%17.64'ünün ise kalıntının yıkanma ile kaybolduğunu belirttiklerini göstermiştir. Görüşülen üreticilerin \%9.38'inin ilaçlama işlemini yaparken herhangi bir önlem almadıklarını belirlenmiştir. Üreticilerin \%4.17'sinin ilaçlama işlemi sırasında önlem olarak eldiven kullandıkları, \%67.71'inin maske kullandıkları, \%18.75'inin ise hem maske hem eldiven kullandıkları belirlenmiştir (Çizelge 17). Anket çalışması yapılan üreticilerin \%65.63'ünün tarımsal mücadele konusunda çok bilgili, \%34.38'inin bilgili ve \%3.13'ünün ise orta derecede bilgi sahibi oldukları tespit edilmiştir (Şekil 6).

Çizelge 16. Üreticilere göre kullanılan ilaçların kalıntı bırakma durumu

Table 16. The residue of the agrochemical used according to the farmers

\begin{tabular}{|c|c|c|c|c|c|c|}
\hline \multirow{2}{*}{$\begin{array}{l}\text { İşletme } \\
\text { genişlik } \\
\text { grupları }\end{array}$} & \multicolumn{2}{|c|}{$\begin{array}{l}\text { Kalıntı } \\
\text { yapar }\end{array}$} & \multicolumn{2}{|c|}{$\begin{array}{c}\text { Kalıntı } \\
\text { yapmaz }\end{array}$} & \multicolumn{2}{|c|}{ Toplam } \\
\hline & $\mathrm{N}$ & $\%$ & $\mathrm{~N}$ & $\%$ & $\mathrm{~N}$ & $\%$ \\
\hline 1 & 49 & 100 & 0 & 0.00 & 49 & 100 \\
\hline II & 23 & 100 & 0 & 0.00 & 23 & 100 \\
\hline III & 10 & 76.92 & 3 & 23.08 & 13 & 100 \\
\hline IV & 11 & 100 & 0 & 0.00 & 11 & 100 \\
\hline Toplam & 93 & 96.88 & 3 & 3.13 & 96 & 100 \\
\hline
\end{tabular}

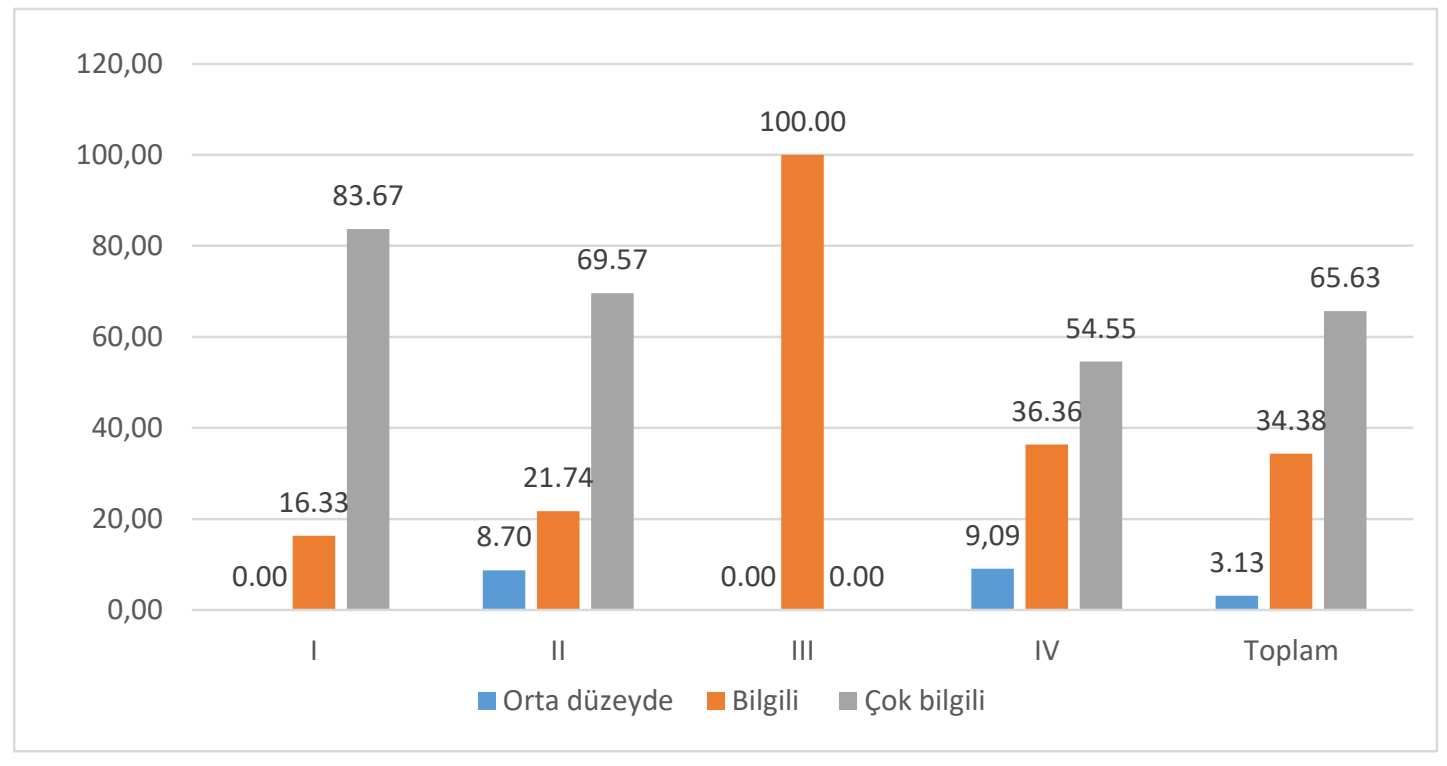

Şekil 6. Üreticilerin tarımsal mücadele bilgi düzeyleri

Figure 6. Knowledge level of producers in diseases-pests

Çizelge 17. Üreticilerin ilaçlamada önlem alma durumu

Table 17. Producers' status of taking measures in spraying

\begin{tabular}{|cccccc|}
\hline $\begin{array}{c}\text { Işletme genişlik } \\
\text { grupları }\end{array}$ & Önlem almıyor & Eldiven & Maske & Hem eldiven hem maske & Toplam \\
\cline { 2 - 6 } & & & Oran (\%) & & \\
\hline I & 10.20 & 2.04 & 69.39 & 18.37 & 100 \\
\hline II & 0.00 & 4.35 & 82.61 & 13.04 & 100 \\
\hline III & 30.77 & 0.00 & 46.15 & 23.08 & 100 \\
\hline IV & 0.00 & 18.18 & 54.55 & 27.27 & 100 \\
\hline Toplam & 9.38 & 4.17 & 67.71 & 18.75 & 100 \\
\hline
\end{tabular}

Görüşülen üreticilerin $\% 81.25^{\prime}$ inin yüksek dozda ilaç kullanmayı tercih ettikleri, \%27.19'unun yüksek dozda ilaç kullanmayı tercih etmedikleri tespit edilmiştir.

Üreticiler yüksek dozda ilaç kullanmayı tercih etmelerinin en önemli sebebinin \%55.48 oran ile ilacın hastalık ve zararlılara karşı etkisiz etki etmemesi olarak belirlenmiştir. Üreticilerin yüksek doz tercih etme sebeplerinin \%32.60'sının dozun yeterli gelmemesi, \%18.18'inin zararlıların ilaçlara karşı bağışıklık geliştirmesi ve \%1.73'ünün ise hastalık ve zararlıların çok olması olarak belirlenmiştir (Çizelge 18). 
Çizelge 18. Üreticilerin yüksek doz tercih etme sebepleri Table 18. Farmer's reasons to prefer high dose spraying

\begin{tabular}{|c|c|c|c|c|c|}
\hline \multirow{2}{*}{$\begin{array}{l}\text { İşletme } \\
\text { genişlik } \\
\text { grupları }\end{array}$} & $\begin{array}{l}\text { Dozun yeterince } \\
\text { etkili olmaması }\end{array}$ & $\begin{array}{c}\text { Zararlıların bağışıklık } \\
\text { kazanmaları }\end{array}$ & $\begin{array}{c}\text { İlacın etkisiz } \\
\text { olması }\end{array}$ & $\begin{array}{c}\text { Hastalık ve zararlıların } \\
\text { çok olması }\end{array}$ & Toplam \\
\hline & \multicolumn{5}{|c|}{ Oran (\%) } \\
\hline 1 & 16.33 & 0.00 & 83.67 & 0.00 & 100.00 \\
\hline II & 52.17 & 0.00 & 43.43 & 4.40 & 100.00 \\
\hline III & 34.64 & 23.08 & 42.28 & 0.00 & 100.00 \\
\hline IV & 27.27 & 18.18 & 52.55 & 2.55 & 100.00 \\
\hline Toplam & 32.60 & 10.31 & 55.48 & 1.73 & 100.00 \\
\hline
\end{tabular}

\section{SONUÇ ve ÖNERILER}

Bu çalışmada, armut üretim faaliyetinde işletmecilerin kullandıkları girdi miktarları ve kültürel işlemleri belirlenmiştir. Araştırma bölgesi olarak Antalya ili Korkuteli ilçesi seçilmiştir. Çalışmada üreticilerin armut üretimini 20 yıldan fazla bir süredir sürdürdüğü, Korkuteli Karyağdı ve Margarit çeşidinin fazla olarak yetiştirildiği saptanmıştır. Damla sulama bölgede yaygınlaşmıştır. Yüksek düzeyde gübre kullanımı bulunmaktadır. İşgücü kaynağı olarak aile işgücü önemlidir. Ancak işletme ölçeği artığında yabancı işgücü, işgücü ihtiyacının nerede ise tamamını karşılamaktadır. Üreticilerin yarıdan fazlası armut yetiştiriciliğinde bilgi düzeylerinin yüksel olduğunu ifade etmiş̧ir. Buna karşın önemli bir kısmı armut yetiştiriciliğinden memnun olmadıklarını bildirmiştir. Bölgede klasik yetiştiricilik sistemi egemendir.

Bölgede armut tarımında yüksek miktarlarda girdi kullanımı düzeyleri söz konusudur. Özellikle bölgedeki çiftçiler armut üretiminde girdi kullanım çeşitleri, kullanım zamanı, kullanım miktarı ve uygulama şekli konularında bilinçlendirilmelidir. Ayrıca yıllar itibariyle girdi unsurlarının fiyatlarındaki yükselmeler ve ürün fiyatının oynaklığı çiftçilerin memnuniyet seviyesini etkileyebilmektedir.

\section{ÖZET}

Amaç: Bu çalışmada, Antalya ili Korkuteli ilçesinde armut üretim faaliyeti yapan tarım işletmelerinin bu üründe kullandıkları girdi ve kültürel işlemlerinin belirlenmesi amaçlanmıştır.

Yöntem ve Bulgular: Araştırma kapsamında birincil veriler yüz yüze anket yöntemiyle 96 adet armut işletmesinden elde edilmiştir. Araştırma verileri 2018 üretim dönemine aittir. Çalışmada üreticilerin armut üretimine ilişkin bilgileri, yetiştirdikleri çeşitler, ağaç sayıları, uyguladıkları kültürel işlemler, girdi kullanımı ve en fazla etkilendiği hastalık ve zararlılar tespit edilmiştir. İşletmeler armut alanına göre gruplandırılmıştır. Elde edilen bulgular çapraz tablolar ile verilmiştir. Görüşülen üreticilerin bitkisel üretimde deneyiminin $27.75 \mathrm{yıl}$, armut üretiminde deneyimi ise 22.93 yıldır. Üreticilerin yarıdan fazlası $\left(\% 52.21^{\prime} i\right)$ armut yetiştiriciliği konusunda bilgi düzeylerinin yüksel seviyede bildirmiştir. Çiftçilerin önemli bir kısmı (\%74.04'ü) armut yetiştiriciliğinden memnun olmadıklarını ifade etmiştir. Çalışmanın yapıldığı bölgede üreticilerin tamamına yakını (\%93.75'i) klasik yetiştiricilik sistemi uygulamaktadır. Araştırma bölgesinde görüşülen işletmelerin armut alanının \%48.56'sını Korkuteli Karyağdı çeşidi, \%28.13'ünü ise Margarit çeşidi oluşturduğu belirlenmiştir. En önemli hastalığın ateş yanıklığı, en önemli zararlının armut psillidi olduğu saptanmıştır. Görüşülen işletmelerin armut üretiminde dekar başına ortalama $45.71 \mathrm{~kg}$ azot, $35.46 \mathrm{~kg}$ fosfor ve $10.04 \mathrm{~kg}$ potasyum kullandıkları hesaplanmıştır. Bunun yanı sıra armut üretiminde kullanılan dekara ortalama fungusit miktarı $1182.26 \mathrm{gr}$, insektisit miktarı $403.90 \mathrm{gr}$ ve herbisit miktarı ise 166.73 gr olarak hesap edilmiştir.

Genel Yorum: Bölgede ele alınan üreticilerin armut üretiminde deneyim sürelerinin ve bilgi düzeylerinin yüksek olduğu saptanmıştır. Buna karşın memnuniyet düzeyleri düşük ifade edilmiştir. Bunun nedenleri yıllar itibariyle girdi unsurlarının fiyatlarındaki yükselmeler ve ürün fiyatının oynaklığı olarak ifade edilir. Girdi kullanımı düzeylerinde yüksek miktarlar söz konusudur. Bu açıdan üreticiler girdi kullanımı, zamanı, miktarı, uygulama şekli gibi konularda daha fazla bilinçlendirilmelidir.

Çalışmanın Önemi ve Etkisi: Armut üretiminin teknik özellikleri ilgili çalışmalar oldukça sınırlı olması bu çalışmanın özgünlüğünü arttırmaktadır. illgili araştırmacılara çiftçilerin çeşitli teknik uygulamaları sunulmuştur. Bu açıdan armut üretiminde teknik yapıdaki iyileştirmelerin hangi noktalarda olması gerektiğinin üzerinde de düşünce sağlayacaktır.

Anahtar Kelimeler: Antalya, Korkuteli, armut, teknik özellikler, yetiştiricilik. 


\section{ÇIKAR ÇATIŞMA BEYANI}

Yazar(lar) çalışma konusunda çıkar çatışmasının olmadığını beyan eder.

\section{ARAŞTIRMACILARIN KATKI ORANI BEYANI}

Yazarlar çalışmaya eşit oranda katkı sağlamış olduklarını beyan eder.

\section{KAYNAKLAR}

Davis PH (1972) Flora of Turkey and the East Aegean Islands. Vol. 4. Edinburgh, Edinburgh University Press, pp. 135-136, 162-163.

Erbaşlar Ö (2014) Bursa İli Armut Üretiminde Tarımsal İlaç Kullanımının Ekonomik Analizi. Yüksek Lisans Tezi, Uludağ Üniversitesi, Fen Bilimleri Enstitüsü

Gürel S (2013) Bursa Yöresinde Armut Plantasyonlarında Görülen Mikro Besin Elementleri (Fe, $\mathrm{Zn}$ ve $\mathrm{B}$ ) Noksanlıklarının Teşhisi ve Giderilmesi. Yüksek Lisans Tezi, Uludağ Üniversitesi Fen Bilimleri Enstitüsü
MAREM 60 (2014) Armut Yetiştiriciliği Yayını. MAREM, I. Baskı, Isparta.

MEGEP (2009) Bahçecilik, Armut Yetiştiriciliği. Mesleki Eğitim ve Öğretim Sisteminin Güçlendirilmesi Projesi Yayınları, 24-26s, 36 s, Ankara.

Özçağıran R, Ünal A, Özeker E, İsfendiyaroğlu M (2004) Ilıman İklim Meyve Türleri. Yumuşak Çekirdekli Meyveler 2, 200.

Yamane T (2001) Basic Sampling Methods. Translators: A. Esin, M.A. Bakır, C. Aydın, E.Gürbüzsel, Publishing of Literatür, No: 53, İstanbul. 